\title{
Introduction
}

\section{Population Displacements: Causes and Consequences}

\author{
Ogenga Otunnu
}

W hile the international community is frantically engaged in developing more credible terror policies against refugees and immigrants and is feverishly occupied with the politics of the U.S.-led war on terrorism, over thirty million internally displaced people endure persecutions and remain caged in turbulent and inhumane conditions in their home countries. Some fifteen million externally displaced persons or refugees also languish outside their home countries without basic human rights and human security. These victims of violations of human rights and political violence are uprooted from their homes by a number of interrelated factors, internal and external, past and present.

Historically, mass displacements of populations have been intimately linked with violently contested legitimacy of the state, its institutions, and their incumbents. Legitimacy of the state demands that the construction and/or the preservation of the political entity reflect the vital interests, values, and expectations of its members. Human rights, including the rights to development, human security, and social justice, are central to the political legitimacy of the state and its institutions. When a state meets these criteria, its members, in turn, will identify and co-operate with it and its institutions. Such a state, whose sovereignty is derived from its members, is also likely to conform to international norms, customs, principles, conventions, and obligations by which relations between states and international persons are governed.

States that are major sources of contemporary displacements of populations, however, suffer from a profound and chronic legitimation deficit. The origins of this pervasive and harrowing crisis of legitimacy reflect how these predatory juridical states were constructed and preserved. In Africa, Asia, the Middle East, and Latin America, these states were constructed to meet the vaulting socio-econo- mic, strategic and political interests of imperial powers. Since the primary motives for imperialism did not conform to the interests, values, and expectations of the conquered and dehumanized inhabitants of the colonial creations, the states experienced profound crises of legitimacy. These states also became important sites of violations of human rights and political violence, including terror.

The profound legitimation deficit of the state and its incumbents was exacerbated by the imperial violence that accompanied colonial state formations. This violence included herding the target populations into concentration camps, scorched-earth policies, patronage, and manipulation of nationality and/or religious contradictions. Many lives were lost and many inhabitants of the colonial territories were violently uprooted as well.

The notoriously arbitrary boundaries of these states intensified the crisis of legitimacy of the faltering colonial states. Paper boundaries, which were imposed on these societies, often cut across national, cultural, linguistic, and economic entities. For example, in the Middle East, the Kurds and the Palestinians were displaced and left stranded in many neighbouring countries. Similarly, in Africa, the Akan, Ewe, Yuruba, Hutu, Tutsi, and Somalis, for example, found themselves in a number of colonial states. The imposed and hostile boundaries, compounded by colonial administrative and economic policies, also left some of the states so small or immense in area or population that they were not viable entities.

Although during anti-colonial struggles some local political leaders had criticized the artificial nature of the boundaries, as soon as they assumed power they defended the boundaries. Where national groups demanded self-determination, the new rulers used the same institutions and agents of terror to suppress such demands. The politics of 
national integration, through administrative fiat, were also characterized by political violence, political manipulation, and displacements of populations.

These fractured societies also inherited imperial economic policies that created absolute dependency on the imperial powers and led to the vertical integration of the economies into the international economic system. In Latin America, for example, imperial economic policies-characterized by plunder of minerals, forced labour in the mines, and the enslavement of Africans-turned the states into suppliers of raw materials to industrializing Europe. The development of the economies of the imperial powers that controlled Africa, Asia, and the Middle East was part of a similar dialectical process.

These structures of severe exploitation, underdevelopment, and dependency are more embedded today than during the period of formal colonialism. Contemporary economic decay also stems from corruption by local rulers, lack of political accountability, widespread nepotism, militarism, economic mismanagement, political instability, the debt crisis and the politics of international economic system, multinational corporations, private banks, globalization, the World Bank, and the International Monetary Fund (IMF). These crises have compelled some states, including Uganda, not only to rely on foreign loans and foreign aid for their annual budgets, but also to hand over the (mis)management of their economies to the World Bank and the IMF.

These economic crises-which leave the industrialized countries, with approximately 20 per cent of the global population, an island in a violent sea of poverty-condemn over one billion people in the underdeveloped world to absolute poverty. Absolute poverty means poor health, high incidence of HIV/AIDS, high infant mortality, lack of adequate and proper nutrition, lack of relevant education, mass unemployment, persistent insecurity and hopelessness, increased crimes, and life-threatening labour. The crises also intensify struggles over scarce resources and lead to widespread violence, political repression, torture, and displacements of population. Ironically, victims of national and international economic cum political policies, past and present, who seek asylum, are dismissed as bogus refugees or economic refugees.

Another significant cause of displacements of populations in these states is dictatorship. This dominant factor draws heavily from the colonial heritage, when institutions, policies and rule rested on terror and authoritarianism. Whether or not the retreating colonial powers introduced colonial versions of experimental democracy, refugee-producing states in Africa, Asia, Latin America, and the Middle East experienced some forms of revolutionary dictatorship or single-party dictatorship or civilian cum military dictatorship. In these states, dictators dismissed democratic pluralism as a Western form of government that did not fit situations in underdeveloped societies. Some dictators promised to allow democratic pluralism in the future, when what is historically necessary to provide political legitimacy and durable peace is historically possible.

Dictatorships, even when they are described by some Western leaders and scholars as African or Asian democracy, have led to disappearances of political opponents, detention and torture, political repression, militarization of society, and displacements of populations. Since avenues for peaceful transition of power are blocked or socio-economic and political exclusion has intensified, some political opponents have engaged in armed violence against the incumbents and their supporters. Often, armed encounters develop into civil wars and uproot more people from their homes.

During the Cold War, the two leading hegemonic powers, the U.S. and the Soviet Union, took advantage of internal conflicts and violence in some of these states. In the violent scramble, the superpowers and their allies in Europe and/or North America provided substantial arms and political and economic support to corrupt and despotic regimes or despotic opposition groups in these predatory states. While this struggle for global hegemony was a form of cold war between the superpowers, there were hot wars that destroyed hundreds of thousands of lives, maimed and violently uprooted millions of people, further undermined the legitimacy of the faltering states, and decimated the economies of the victim/client states. For example, superpower rivalry turned Afghanistan into a battlefield that claimed over a million lives, permanently maimed over three hundred thousand Afghans, generated over six million refugees, and left over a million internally displaced people. The war between the Soviet-backed regime in Kabul and the Mujahedeen armed opposition (supported by the U.S., Saudi Arabia, and Pakistan) also destroyed cities, schools, hospitals, pastures, and livestock, and left millions of anti-personnel mines in the ravaged and poverty-stricken country. The displacement of population continued during the U.S.-led war against the Taliban.

Internal wars, violent conflicts, severe socio-economic crises, and systematic violations of human rights have contributed to a number of genocides and displacements of populations. Genocidal societies are critically polarized, have a long history of violent conflicts and policies of exclusion, and experience socio-economic hardships. Often, the victims or target groups are identified in terms of nationality, race, political ideology, and/or religious affiliation. Perpetrators of genocide use effective and dehumanizing propaganda and slogans to present the "other" as 
subhuman, evil, and a threat to the survival and prosperity of the society. In such situations, genocide, including mass rapes and ethnic cleansing, is disguised as a normal response to extraordinary crises and a patriotic duty.

Population displacements and destruction of human lives and property also result from "environmental violence," including the ravages of cyclones, tidal surges, hurricanes, floods, earthquakes, volcanic eruptions, pollution, droughts and famines, "development projects" or "development" policies and deliberate destruction of the "enemy's environment." Although such displacements are often caused by a complex combination of socio-economic and political policies and "ecological violence," both local and international, displaced victims, including those who cross international borders in search of asylum, are labeled "environmental refugees" or "environmental migrants." Such labels not only exclude the externally displaced, who flee life-threatening violence, from qualifying for refugee status, but they also gloss over socio-economic and political conditions under which displacements occur.

Another type of environmental violence is landmines, used in insurgency/counter-insurgency warfare to kill, terrorize, maim, and displace unarmed civilians. Landmines also prevent victims of violations of human rights and political violence from fleeing to safe zones, thereby forcing the uprooted population to languish without protection and assistance. In addition, tens of millions of these unexploited blind weapons of mass destruction, scattered in at least sixty-two countries, prevent safe repatriation and resettlement, intensify poverty and underdevelopment, and hinder humanitarian assistance and post-conflict rehabilitation and reconstruction.

The consequences of displacements are especially severe for the victims. Many perish, while many more are tortured, terrorized, detained, raped, harassed, humiliated, dehumanized, traumatized, and left without protection. The overwhelming majority of these victims of systematic violations of human rights languish in hostile, war-torn and poverty-stricken countries. Whether they are caged in lifethreatening concentration camps in Northern Uganda or confined to hostile refugee camps in Pakistan, or are in prison-like detention centres in Europe or locked up with criminals in prisons in the U.S., the uprooted population know that countries of the industrialized Western Europe and North America, that claim to champion human rights and democracy, support regimes that champion violations of human rights and despotism. They also know that the champions of human rights and democracy defend forced repatriation, interdiction, and detention of asylum seekers and immigrants. They are then compelled to conclude that human rights in practice only apply to those who are racially, economically, and political relevant.

These voices that some scholars and the media ignore seem to have been vindicated by the growing xenophobia and asylum and immigration terror policies. Anti-refugee and anti-immigrant terror policies in industrialized Western Europe and North America have been conveniently justified as war against international terrorism. The war against international terrorism has also attracted the support of some rulers from the underdeveloped countries who are terrorists and major violators of human rights in their own countries.

This issue of Refuge examines some causes and consequences of displacements of populations. Anita Gagnon, Lisa Merry, and Cathlyn Robinson highlight some of the effects of forced displacement on refugee women's reproductive health. Their extensive literature review revealed a paucity of data to support or refute claims of greater reproductive health risks for refugee women. The authors encourage policymakers, practitioners, activists, and scholars to pay special attention to this group.

Maureen Lynch focuses on environmental consequences of forced displacement. Drawing from her distinguished field experience and case studies, she presents an elaborate list and analysis of environmental problems that big refugee settlements cause. These problems also generate socio-economic and political tension between refugees and host communities. Although there are no easy solutions to the complex problems - compounded by chronic poverty, lack of resources, and lopsided policies-she suggests underlying principles that can mitigate some of the problems.

Michelle Lowry provides an analysis of some of the effects of displacement of populations on refugee and immigration policies in Canada. The growing anti-refugee and anti-immigrant policy in Canada, which mirrors the harmonized policies in industrialized Europe and North America against refugees and immigrants from underdeveloped countries, is presented by the government in terms of national security. Using a feminist approach to examine the contradictions between national security and human security, the article demonstrates how the new policy creates insecurity for refugees and migrants, discriminates against refugee women and children, exacerbates racism, and undermines Canada's policy of multiculturalism. In addition, the article observes that Canada's definition of "terrorism" ignores the fact that some people and groups in underdeveloped countries are engaged in wars against violent and oppressive regimes.

Anthony H. Richmond's article is an excellent examination of social exclusion or global apartheid, which is both a cause and effect of displacement and instability. Although 
the study focuses largely on Britain, it provides useful examples of global social exclusion, including genocide, xenophobia, globalization, discrimination, racism, and deportations. The article also demonstrates that contemporary responses to perceived threats of mass migrations to industrialized societies rely on instruments of global apartheid: forcible repatriation of refugees to the so-called "safe third countries," interdiction, visas, and denial of citizenship.

MacDonald E. Ighodaro provides a critical analysis of theories and practices of repatriation. Applying critical anti-racist discursive frameworks, the article highlights the politics and failure of one of the so-called durable solutions to the refugee crises: voluntary repatriation. It also demonstrates that the overwhelming majority of refugees are forced to repatriate during violent conflict because asylum is a tragic myth. Unless the causes of displacements are addressed, including historical and contemporary oppression, exploitation, dictatorship, and systematic violations of human rights, the paper concludes that the African refugee crises in particular will defy imposed and discriminatory durable solutions.

Ogenga Otunnu is an assistant professor of refugee studies, contemporary global issues, and African history at DePaul University in Chicago. Dr. Otunnu has also taught at York University in Toronto. He has published on democratization in Africa, refugee crises, conflict resolution, genocide, and political violence. 